\title{
HIGHER ORDER THINKING SKILLS (HOTS) DALAM PEMBELAJARAN BAHASA INGGRIS SD/ MI DI ERA REVOLUSI INDUSTRI 4.0
}

\author{
Ulva Fatiya Rosyida \\ STAI Al Muhammad Cepu, Cepu Indonesia \\ e-mail: ulvablora@gmail.com
}

\begin{abstract}
Today, English for students of Elementary School is not included in the curriculum. It has been only taught as an additional subject or Mulok. This policy should be revised since Indonesia has been going towards 4.0 Industry Revolution Era. In this era, there is a blended global digital interaction between online and industry. Here, English is really needed for getting and with English is very crucial. Besides, they should have Higher Order Thinking Skills or HOTS to face this era. Having English skill and HOTS, the Indonesian students and people are ready to compete with all competitors around the world.
\end{abstract}

Keywords: HOTS, English for Elementary School, 4.0 Industry Era

\begin{abstract}
Abstrak
Saat ini, bahasa Inggris untuk siswa Sekolah Dasar tidak termasuk dalam kurikulum. Itu hanya diajarkan sebagai subjek tambahan atau Mulok. Kebijakan ini harus direvisi karena Indonesia telah menuju Era Revolusi Industri 4.0. Di era ini, ada interaksi digital global campuran antara online dan industri. Di sini, bahasa Inggris sangat dibutuhkan untuk mendapatkan dan berbagi informasi di seluruh dunia. Karena itu, mempersiapkan siswa muda dengan bahasa Inggris sangat penting. Selain itu, mereka harus memiliki Keterampilan
\end{abstract}


Berpikir Tingkat Tinggi atau HOTS untuk menghadapi era ini. Memiliki keterampilan bahasa Inggris dan HOTS, siswa dan orang-orang Indonesia siap bersaing dengan semua pesaing di seluruh dunia.

Kata kunci: HOTS, Bahasa Inggris untuk Sekolah Dasar, Era Industri 4.0

\section{A. Pendahuluan}

Tahun 2018 merupakan awal dimulainya Revolusi Industri 4.0.Hal ini ditandai dengan adanya penggunaan digital. Di samping itu, akan terjadi komunikasi antara mesin "Internet of Things (IoT)" dengan orang-orang "Internet of People (IoP)" (https:// jurnalmanajemen.com/revolusi-industri-4-0/). Berbagai peluang dan tuntutan tidak memberikan tawaran lain bagi Indonesia kecuali harus siap menghadapinya. Hal ini tentu menuntut perhatian dari semua sektor terutama sektor pendidikan yang menempati garda terdepan dalam pembangunan sumber daya manusia agar berdaya saing tinggi.Kondisi tersebut juga berpengaruh terhadap pentingnya kemampuan berbahasa terutama bahasa Inggris sebagai alat vital dalam komunikasi global.

Terkait dengan pentingnya kemampuan berbahasa, pemerintah melalui Kementerian Pendidikan dan Kebudayaan menginstruksikan, mulai tahun ajaran 2015/2016 seluruh sekolah menerapkan tiga bahasa, yakni bahasa Indonesia, bahasa Inggris dan bahasa daerah. Hal ini diharapkan agar ketiganya dapat berjalan beriringan tanpa ada yang terabaikan (www.indopos.co.id).Bahasa Indonesia sebagai bahasa nasional, pengantar pendidikan, bahasa daerah sebagai salah satu khazanah budaya Indonesia, sedangkan bahasa Inggris sebagai modal komunikasiinternasional.

Namun, kebijakan pemerintah lainnya terkait dengan bahasa justru kurang mendukung posisi bahasa Indonesia yang juga diusung sebagai bahasa ASEAN. Salah satu penyebabnya adalah dihapuskannya kebijakan tentang kewajiban TKA (Tenaga Kerja Asing) di Indonesia yang harus mampu berbahasa Indonesia. Kebijakan tersebut tertuang dalam Permenaker No 16 Tahun2015. 
Mengetahui kondisi tersebut, tidak dapat ditawar lagi bahwa memiliki kemampuan berbahasa Inggris merupakan suatu keharusan dan harus segera dimulai sejak dini, minimal di bangku Sekolah Dasar. Sayangnya, bahasa Inggris bukan menjadi mata pelajaran pokok SD/ MI melainkan sebagai mata pelajaran tambahan atau Muatan Lokal (Mulok).Itu pun tidak semua sekolah mengajarkannya, atau minimal diajarkan di kelas 4, 5, atau hanya di kelas 6 SD (tergantung kebijakan sekolah masing-masing).

Makalah ini akan memaparkan pentingnya memasukkan mata pelajaran Bahasa Inggris dalam kurikulum Sekolah Dasar mengingat tuntutan persaingan digital yang semakin mengglobal. Beberapa poin yang akan dipaparkan dalam makalah ini meliputi sekilas tentang HOTS dan Revolusi Industri 4.0, Kebijakan Pemerintah terkait Pendidikan Bahasa di Indonesia, serta bagaimana Pendidikan Bahasa Inggris bagi siswa SD/MI yang berorientasi HOTS di Era Revolusi Industri 4.0.

\section{B. Pembahasan}

\section{Higher Order Thinking Skill (Hots) Dan Revolusi Industri4.0}

Kemampuan berpikir tingkat tinggi atau yang sering disebut sebagai Higher Order Thinking Skilsl atau HOTS merupakan proses berfikir yang mewajibkan siswa memanipulasi informasi dan ide-ide dengan cara tertentu yang memberi mereka pengertian dan implikasi baru (Gunawan, 2012:171). Pendapat lain mengatakan bahwa HOTS merupakan cara berfikir yang tidak hanya menghafal secara verbal melainkan mampu memaknai hakikat yang terkandung di dalamnya yang meliputi kemampuan analisis, sintesis, mengasosiasi hingga menarik kesimpulan menuju penciptaan ide-ide kreatif dan produktif (Ernawati, 2017:196-197). Dengan demikian, HOTS merupakan kemampuan menganalisis, mengevaluasi, dan mengkreasi informasi untuk memecahkan berbagai persoalan

Selain itu, pembelajaran bahasa berorientasi HOTS merupakan pembelajaran berdasarkan situasi nyata dalam kehidupan sehari-hari. Hal ini sejalan dengan pentingnya penggunaan authentic materials (bahan ajar otentik) dalam pembelajaran bahasa.Dengan demikian, 
siswa diharakan dapat menerapkan konsep-konsep pembelajaran di kelas untuk memecahkan persoalan, termasuk kesiapan menghadapi Revolusi Industri.

Revolusi Industri telah mengalami tiga revolusi besar sepanjang sejarah.Revolusi Industri 1.0 adalah revolusi mekanik yang ditandai dengan penemuan mesin bertenaga uap dan air pada akhir abad ke 18. Revolusi Industri 2.0 terjadi pada tahun 1870 merupakan Revolusi Listrik yang ditandai dengan produksi mesin bertenaga listrik.Pada masa ini mulai diciptakan mobil, pesawat terbang, pesawat telepon, dsb. sedangkan Revolusi Industri 3.0 terjadi pada tahun 1969 disebut Era Informasi yang ditandai dengan banyaknya perkembangan elektronik dan teknologi informasi (https://jurnalmanajemen.com/revolusi-industri-4-0/).

Revolusi Industri 4.0, sebagaimana disebutkan dalam bab pendahuluan, dimulai sejak tahun 2018. Revolusi ini didasari keinginan untuk meningkatkan kualitas hidup manusia di seluruh dunia melalui akses dunia digital.Saat ini, masyarakat mulai dimanjakan dengan pelayanan online yang mudah, murah, praktis, dan ekonomis. Mulai dari memesan ojek atau taksi online, belanja, tiket kereta api, pesawat, hotel, pembayaran tagihan listrik, internet, dsb., semuanya serba online. Dengan demikian, memiliki kemampuan berpikir tingkat tinggi (HOTS) serta mampu berkomunikasi dalam bahasa Inggris sebagai bahasa internasional merupakan suatu keharusan.

\section{Kebijakan Pendidikan Bahasa Inggris Di Indonesia}

Kebijakan pendidikan bahasa asing, khususnya bahasa Inggris di Indonesia sudah dimulai pada tahun 1950-an. Pada masa itu, bahasa Inggris mulai diajarkan pada tahun 1952 untuk jenjang Sekolah Menengah Atas dan tahun 1962 untuk jenjang Sekolah Menengah Pertama dengan porsi 2-4 jam per minggu (Djojonegoro, 1996:129136). Selanjutnya, bentuk-bentuk kebijakan pendidikan bahasa Inggris di Indonesia dituangkan dalam beberapa peraturanberikut:

1. UU No 20 Tahun 2003 tentang Sistem Pendidikan Nasional, pasal 33 ayat (3) menyatakan bahwa bahasa asing dapat 
digunakan sebagai bahasa pengantar pada satuan pendidikan tertentu untuk mendukung kemampuan berbahasa asing pesertadidik.

2. Permendiknas nomor 23 tahun 2006 tentang Standar Kompetensi Lulusan (SKL) untuk Satuan Pendidikan Dasar dan Menengah, Kompetensi bahasa-termasuk bahasa Indonesia dan bahasa Inggris-yang harus dikuasai adalah menyimak, berbicara, membaca, dan menulis sesuai jenjang pendidikan sebagai berikut (Lampiran Permendiknas nomor 23 tahun 2006):

a. SD/MI/SDLB/PaketA

1) Menunjukkan kegemaran membaca dan menulis

2) Menunjukkan keterampilan menyimak, berbicara, membaca, menulis, dan berhitung.

b. SMP/MTs./SMPLB/PaketB

1) Menunjukkan kegemaran membaca dan menulis naskah pendeksederhana

2) Menunjukkan keterampilan menyimak, berbicara, membaca, dan menulis dalam bahasa Indonesia dan bahasa Inggrissederhana.

c. SMA/MA/SMALB/PaketC

1) Menunjukkan keterampilan membaca dan menulis naskah secara sistematis danestetis

2) Menunjukkan keterampilan menyimak, membaca, menulis, dan berbicara dalam bahasa Indonesia dan Inggris.

d. SMK/MAK

1) Menunjukkan keterampilan membaca dan menulis naskah secara sistematis danestetis

2) Menunjukkan keterampilan menyimak, membaca, menulis, dan berbicara dalam bahasa Indonesia dan Inggris.

Dari uraian di atas, nampak bahwa bahasa Inggris tidak dimasukkan dalam Standar Kompetensi Lulusan (SKL) pada 
Satuan Pendidikan Dasar namun sebagai muatan lokal maupun ekstrakurikuler.

3. UU nomor 24 tahun 2009 tentang "Bendera, Bahasa, dan Lambang Negara, serta Lagu Kebangsaan” bab III "Bahasa Negara", pasal 29 ayat (3) menyebutkan bahwa Penggunaan Bahasa Indonesia sebagaimana dimaksud pada ayat (1) tidak berlaku untuk satuan pendidikan asing atau satuan pendidikan khusus yang mendidik warga negaraasing.

Jadi, pemerintah memberi kebijakan bagi warga negara asing yang sedang belajar bahasa Indonesia atau sedang belajar di Indonesia untuk menggunakan bahasa asing sebagai bahasa pengantar pendidikan yang sedang mereka tempuh.

4. Peraturan Presiden No. 57 tahun 2014 tentang Pengembangan, Pembinaan, dan Perlindungan Bahasa dan Sastra, serta Peningkatan Fungsi Bahasa Indonesia, Bab II "Kedudukan dan Fungsi Bahasa", pasal 7 menyebutkan bahwa Bahasa Asing berfungsisebagai:

a) sarana pendukung komunikasiantarbangsa;

b) sarana pendukung penguasaan ilmu pengetahuan, teknologi, dan seni; dan

c) sumber Pengembangan BahasaIndonesia.

Kebijakan ini sejalan dengan pendapat Badudu (1979:7) yang menyatakan bahwa bahasa asing justru dapat memperkaya bahasa Indonesia terutama dari segi perbendaharaan kata.

\section{Pembelajaran Bahasa Inggris Sd/Mi Di Era Revolusi Industri4.0}

Dalam Undang-undang No. 35 tahun 2015 tentang Tata Cara Penerimaan Warga Asing sebagai Perubahan atas Permenaker No. 16 tahun 2015, disebutkan persyaratan TKA hanya berdasarkan kualifikasi pendidikan dan pengalaman kerja. Dengan kata lain, tidak terdapat persyaratan terkait kemampuan berbahasa Indonesia. 
Bagi para investor, mereka merasa diuntungkan karena khawatir hal itu dapat menghambat masuknya TKA mengingat semakin sulitnya Uji Kemahiran Bahasa Indonesia atau UKBI yang diselenggarakan oleh Badan Pengembangan dan Pembinaan Bahasa (Sumber: VOA Indonesia, 2015).

Kondisi tersebut seharusnya dapat dimanfaatkan untuk mempromosikan kekayaan bangsa termasuk mempromosikan Bahasa Indonesia agar menjadi salah satu bahasa besar di dunia dengan memanfaatkan bahasa Inggris.Artinya, orang Indonesia harus mampu berbahasa Inggris untuk kemajuan diri dan bangsanya, bukan untuk motif kegengsian dll (Rahardi, 2006:174). Saat ini, bahasa Indonesia sudah banyak dipelajari oleh beberapa negara di dunia, seperti Cina, Belanda, Jepang, Korea Selatan, Australia, bahkan Amerika Serikat (Muslich,2010:43).

Selanjutnya, terkait dengan kebijakan pendidikan bahasa dalam menghadapi Revolusi Industri 4.0, seperti yang tertulis pada pendahuluan, pemerintah menginstruksikan mulai tahun ajaran 2015/2016, semua sekolah di Indonesia harus menerapkan tiga bahasa, yakni bahasa Indonesia, bahasa Inggris, dan bahasa daerah. Menyikapi hal tersebut, pihak-pihak terkait, khususnya pendidik atau guru bahasa, harus mampu menempatkan diri sebagai agent of curriculum development.Pendapat ini selaras dengan pernyataan Nunan (1999:152) yang meyebutkan bahwa guru juga merupakan curriculum developer yang memiliki tanggung jawab terhadap perubahan kebijakan yang terjadi khususnya dalam bidang pendidikan.

Pendidikan bahasa hendaknya diajarkan sejak masih anakanak. Pada masa itu, mereka berada pada usia emas (golden age). Apapun yang diajarkan, akan melekat kuat dalam memorinya, termasuk bahasa. Bahasa ibu (daerah) biasanya diperoleh langsung dari lingkungan sekitarnya. Pada saat yang sama, bahasa Indonesia juga diperoleh dari komunikasi sehari-hari, dari tayangan TV, dsb. Selanjutnya, bahasa Indonesia diajarkan dan digunakan sebagai bahasa resmi pengantar pendidikan. 
Lalu, kapan anak mulai mengenal bahasa Inggris?Untuk menjawab pertanyaan tersebut, penulis melihat dari kacamata tuntutan global.Saat ini, bahasa Inggris sudah banyak digunakan dan diajarkan di negara-negara ASEAN.Bahkan, bahasa Inggris menjadi bahasa resmi di Singapura.Maka, bahasa Inggris di Indonesia seharusnya diperkenalkan sejak pendidikan pra sekolah dasar. Misalnya, anak-anak diperkenalkan kosakata bahasa Inggris sesuai tingkat perkembangannya.Kemudian, bahasa Inggris dimasukkan dalam mata pelajaran wajib sejak pendidikan dasar sampai perguruantinggi.

Pembelajaran Bahasa Inggris yang berorientasi HOTS bagi siswa $\mathrm{SD} / \mathrm{MI}$ seharusnya memenuhi komponen kompetensi komunikatif. Kompetensi Komunikatif (KK) merupakan tujuan pengajaran bahasa di Indonesia (Madya, 2013:147).Selain itu, berdasarkan tingkat literasi, jenjang Sekolah Dasar berada pada tingkat performance (Wells dalam Hammond, 1992:10).Pada level ini, siswa diharapkan mampu membaca, menulis, dan berbicara dengan simbol-simbol sederhana dalam Bahasa Inggris (Helena, 2008).

Kompetensi komunikatif meliputi 6 komponen, yaitu: Kompetensi Linguistik, Kompetensi Sosiokultual, Kompetensi Strategi, Kompetensi Interaksional, Kompetensi Wacana, Kompetensi Formula (lihat gambar 1).

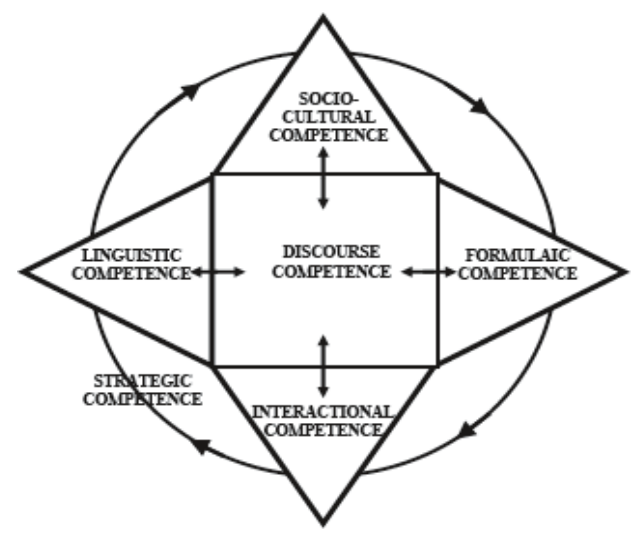

Gambar 1. Kompetensi Komunikatif (Celce-Murcia, 2008:45) 


\section{Kompetensi Linguistik}

Kompetensi linguistik ditandai dengan kemampuan kebahasaan (linguistik) secara struktural.Artinya, struktur kebahasaan terkait dengan pemakaian bahasa yang berterima, baik lisan maupun tulis. Dalam hal ini, siswa diharapkan mampu menciptakan komunikasi yang baik, tidak hanya "asal omong" melainkan lebih terstruktur sehingga lebih mudah dipahami oleh mitra tuturnya.Tentu saja hal ini perlu pembiasaan sejak pendidikan dasar.

Selain itu, kompetensi ini tidak lepas dari system tanda (sign). Tanda-tanda tersebut dapat berupa bunyi, simbol, gambar, kata, dsb.yang telah disepakati masyarakat yang biasanya memiliki latar belakang budaya yang sama. Misal, kata "pokok" pada bahasa Indonesia lebih sering dimaknai sebagai "dasar, inti, penting". Namun, dalam bahasa Melayu Brunei, kata "pokok" tersebut biasa dimaknai "pangkal batang pohon". Contoh berikutnya, kata "kapan" dalam bahasa Indonesia bermakna menunjukkan waktu, sedangkan dalam bahasa Melayu Singapura,kata "kapan" selain menunjukkan waktu, bisa juga dimaknai sebagai “kafan (kain)". Sama halnya ketika suatu istilah dalam bahasa Inggris memiliki makna lebih dari satu bergantung pada konteks, misalnya istilah "interest" (diterjemahkan menjadi bunga bank atau tertarik), "memory" (diterjemahkan sebagai kapasitas suatu perangkat atau daya ingatseseorang).

\section{Kompetensi sosio kultural}

Kompetensi ini terkait dengan sosial budaya pada masyarakat pengguna bahasa.Bahasa sering dianggap sebagai produk sosial atau produk budaya (Sumarsono, 2002:20). Misalnya berkaitan dengan umur, gender, status sosial, hubungan emosional, kekuasaan, dsb. Hal ini berpengaruh terhadap pilihan kata, ragam bahasa, kesopanan, dll.Seorang penutur sebaiknya memahami nilai sosial supaya dapat berbicara dengan sopan (Holmes, 1992:297).Kompetensi ini juga berkaitan dengan konteks budaya dan konteks situasi.Sebagai contoh, salah satu kajian dalam kompetensi Sosiokultural adalah Politeness (kesantunan). Misalnya, kapan seseorang menggunakan kata please, excuse me, dsb. dalam situasi formal maupun informal. 


\section{Kompetensi Strategi}

Kompetensi strategi mengacu pada kemampuan mengelola komunikasi (terutama lisan) agar tetap berjalan meskipun pembicara mengalami kesulitan- kesulitan, misalnya keterbatasan kosakata. Jadi, kemampuan menguasi strategi dapat menutupi kekurangan kita dan komunikasi tidak terhenti begitu saja. Strategi ini dapat dilakukan secara verbal maupun nonverbal, seperti penggunaan gesture, deskripsi atau penggambaran sesuatu, dsb (Celce-Murcia dkk,1995:21).

Misalnya, ketika siswa tidak tahu kata caterpillar, dia menjelaskan dengan mengatakan You know... green thing... on a tree... walking like this (sambil memperlihatkan gerakan jari tangan seperti ulat berjalan). Berikutnya adalah bagaimana cara meminta penjelasan dari lawan bicara baik langsung maupun tak langsung. Misalnya, What did you say?, You mean..., dan sebagainya. Jika guru sering menggunakannya ketika mengajar, siswa semakin terbiasa mendengarkan dan mempraktekkannya.Hal ini dapat menjadi pembiasaan yang berguna.

4. Kompetensi Interaksional

Kompetensi interaksional terkait dengan kompetensi tindak bahasa (actional competence) yang mengacu pada komunikasi bahasa lisan dan "langkah retorika" pada bahasa tulis (celce-Murcia dkk, 1995:18) Misalnya, meminta jasa/layanan, memuji, meminta informasi dan sebagainya. Pada kegiatan pembelajaran, sangatlah penting bagi siswa untuk dibiasakan mendengarkan instruksiinstruksi akademik, seperti Circle the correct answer, Put them away please, dll. sehingga siswa terbiasa dengan berbagai macam instruksi dalam kelas. Pada keterampilan menulis, siswa diberi contoh fiturfitur linguistik apa saja yang diperlukan untuk merealisasi sebuah teks deskriptif, prosedur, dan lain-lain. Misalnya, teks procedure memiliki tujuan komunikatif untuk menjelaskan bagaimana sesuatu langkah-langkah atau urutan prosesnya serta bahan-bahan yang dibutuhkan.Dengan demikian guru bersama siswa menciptakan wacana kelas yang berbahasa Inggris. 


\section{Kompetensi Wacana}

Dalam membangun kompetensi wacana, perlu dikombinasikan dengan pemahaman terhadap komponen kompetensi komunikatif lainnya.Kompetensi ini memberi kesempatan kepada peserta didik untuk terbiasa mengenal bentuk-bentuk wacana dalam bahasa Inggris supaya mereka dapat merasakan manfaatnya secara praktis, baik dalam komunikasi lisan maupun tulis.Hal ini dikarenakan, bagi siswa Indonesia, bahasa Inggris merupakan bahasa ketiga, setelah bahasa daerah dan bahasa Indonesia.Oleh karena itu, pemerolehan bahasa Inggris terasa sulit dilakukan karena harus melalui pengetahuan terlebih dahulu.

Untuk memperoleh pengetahuan tersebut, diperlukan banyak pengalaman. Misalnya, dengan diberikan pemajanan terhadap kosakata sehari-hari atau dalam bentuk "ungkapan jadi" (routine and pattern), misalnya kebiasaan mengucapkan salam saat bertemu teman, menanyakan kabar, atau mengucapkan thank you ketika menutup suatu percakapan, dsb. Dengan demikian, bahasa Inggris akan lebih mudah dikuasai melalui pembelajaran sekaligus pengalaman terkait dengan penggunaannya secara praktis dalam konteks yang nyata dalam kehidupan sosial di masyarakat.

Oleh karena itu, seorang pengajar Bahasa Inggris seharusnya dapat menciptakan wacana sebanyak mungkin supaya siswa terbiasa mendengarkan dan menggunakan ungkapan-ungkapan jadi/rutin dalam Bahasa Inggris.Selain itu, siswa juga perlu dilatih terbiasa menggunakan wacana-wacana lain seperti transaksional dalam jual beli di pasar.Dalam ragam tulis, siswa perlu dibiasakan untuk menulis seperti ucapan ulang tahun, berduka cita, turut berbahagia dan sebagainya.Pada intinya adalah membiasakan siswa dengan teksteks bahasa Inggris yang otentik untuk mengembangkan kompetensi wacana baik lisan maupuntulis.

6. Kompetensi formula

Kompetensi formula berkaitan dengan "bentuk jadi" yang sering digunakan dalam komunikasi sehari-hari (Celce-Murcia, 
2008:47). Kompetensi ini meliputi: bentuk rutin, kolokasi, idiom, maupun bentuk gabungan leksikal.

a. Bentuk Rutin

Contoh: of course, How do you do? I'm fine, thanks; how are you?

b. Kolokasi

Contoh: spend money, statistically significant, tall building

c. Idiom

Contoh: kick the bucket = to die

d. Gabungan leksikal

Contoh: I'mlooking for _. See you (later/tomorrow/ next week,etc)

\section{Simpulan}

Berdasarkan uraian di atas, dapat disimpulkan bahwa Bahasa Inggris menjadi salah satu alat vital dalam menghadapi Revolusi Industri 4.0.Oleh karena itu, sudah selayaknya Bahasa Inggris perlu diajarkan sejak dini. Pemerintah sebaiknya segera merevisi kurikulum Sekolah Dasar dan memasukkan Bahasa Inggris sebagai mata pelajaran yang wajib diajarkan berdasarkan level epistemic dan kompetensi komunikatif (kompetensi linguistik, kompetensi sosiokultural, kompetensi strategi, kompetensi interaksional, kompetensi wacana, dan kompetensi formula).

Untuk mendukung program tersebut, diperlukan pembiasaan pemikiran tingkat tinggi atau Higher Order Thinking Skills (HOTS). Hal ini dikarenakan untuk dapat berkompetensi dalam dunia global yang serba digital, siswa harus mampu berpikir kritis dan kreatif. HOTS dapat dibiasakan dari hal yang paling sederhana seperti penggunaan authentic materials (materi otentik) dalam pembelajaran, penggunaan routines, dsb.sehingga siswa langsung berhadapan dengan fakta-fakta di lapangan. Dengan demikian, HOTS dan Kompetensi Komunikatif merupakan pasangan serasi yang perlu diterapkan dalam pembelajaran Bahasa Inggris sebagai bekal dalam menghadapi Revolusi Industri 4.0. 


\section{DAFTAR PUSTAKA}

Badudu, Yus, Membina Bahasa Indonesia Baku Bandung: Pustaka Prima. 1979

Celce-Murcia, Marianne., Zoltan Dőrnyei, Sarah Thurrell Apedagogical framework for communicative competence: Content specifications and guidelines for communicative language teaching. Diakses, 1995. dari http://www.google.com/search?ie=UTF$8 \&$ oe $=\mathrm{UTF}-8 \&$ sourceid=navclient\&gfns $=1 \& \mathrm{q}=$ actional + comp etence+celce-murcia pada tanggal 18 September 2018.

Celce-Murcia. Rethinking the role of communicative competence in language teaching. In Soler and Jordà (Ed).Intercultural language use and language learning: Spain:Springer. 2008

Djojonegoro, Wardiman. Lima puluh tahun perkembangan pendidikan Indonesia. Departemen Pendidikan dan Kebudayaan: Badan Penelitian dan Pengembangan Pendidikan dan Kebudayaan. 1996

Ernawati, L. (2017). Pengembangan High Order Thinking (HOT) Melalui Metode Pembelajaran Mind Banking Dalam Pendidikan Agama Islam. PROCEEDING, 189.diakses melalu http://bit.ly/2k66VLI pada tanggal 20 September 2019 pukul 14.00 WIB

Gunawan, Adi W. Genius Learning Strategy: petunjuk praktis untuk menerapkan accelerated learning. Jakarta : PT Gramedia Pustaka Utama, 2012

Hammond, J. et.al. (1992). English for social purposes: A handbook for teacher of adult literacy. Australia: Macquarie University.

Helena I.R.ALiteracy principles and classroom management. Semarang: Unpublished. 2008

Holmes, Janet. An introduction to sociolinguistics. New York: Longman Group UK Limited. 1992

Kebijakan terbaru Kemendikbud di tahun ajaran 2015/2016.Diambil pada tanggal 2 Desember 2015 dari www.indopos.co.id.

Madya, SuwarsihMetodologi pengajaran bahasa: Dari era prametode sampai era pascametode. Yogyakarta: UNY Press. . 2013

Elementary Vol. 7 No. 2 Juli-Desember 2019 
Menteri Ketenagakerjaan Republik IndonesiaPeraturan Menteri Ketenagakerjaan Republik Indonesia Nomor 16, Tahun 2015, tentang Tata Cara Penggunaan Tenaga KerjaAsing. .2015

Menteri Ketenagakerjaan Republik Indonesia. Peraturan Menteri Ketenagakerjaan Republik Indonesia Nomor 35, Tahun 2015, tentang Perubahan atas Peraturan Menteri Ketenagakerjaan Republik Indonesia Nomor 16, Tahun 2015 Tata Cara Penggunaan Tenaga KerjaAsing. 2015

Menteri Pendidikan Nasional Republik Indonesia.(2006). Peraturan Menteri Pendidikan Nasional Republik Indonesia Nomor 23, Tahun 2006, Tentang Standar Kompetensi Lulusan Untuk Satuan Pendidikan Dasar Dan Menengah.

Muslich, Masnur. Bahasa Indonesia pada era globalisasi: Kedudukan, fungsi, pembinaan, dan pengembangan. Jakarta: PT. BumiAksara. 2010

Nunan, David. The learner-centerd curriculum. NY: Cambridge University Press.1988

Presiden. Peraturan Presiden Nomor 57, Tahun 2014, tentang Pengembangan, Pembinaan, dan Perlindungan Bahasa dan Sastra, serta Peningkatan Fungsi Bahasa Indonesia. 2014

Rahardi, Kunjana. Dimensi-dimensi kebahasaan: Aneka masalah bahasa Indonesia terkini. Jakarta: Erlangga. 2006

Republik IndonesiaUndang-Undang Republik Indonesia Nomor 20, Tahun 2003, tentang Sistem Pendidikan Nasional. 2003

Republik Indonesia. Undang-Undang Republik Indonesia Nomor 24, Tahun 2009, tentang Bendera, Lambang Negara, Lagu Kebangsaan dan Bahasa. 2009

Revolusi Industri 4.0. Diakses dari https://jurnalmanajemen.com/revolusiindustri-4-0/pada tanggal 18 September 2019 pukul 10.00 WIB

Tes bahasa Indonesia untuk para investor asing, perlukah?Diambil pada tanggal 27 Oktober 2015, dari http://badanbahasa. kemdikbud.go.id/ukbi/. VOA Indonesia. 